DOI: 10.30519/ahtr.949589

Advances in Hospitality and Tourism Research (AHTR)

\title{
USE OF THE RESOURCE CONSUMPTION ACCOUNTING METHOD IN CUSTOMER PROFITABILITY ANALYSIS: A CASE STUDY OF A 5-STAR HOTEL
}

\author{
Ömer Burak PAKSOY ${ }^{1}$ \\ Alanya Alaaddin Keykubat University, Turkey \\ ORCID: 0000-0002-1273-5915
}

\begin{abstract}
This study was designed to illustrate the implementation of customer profitability analysis (CPA) using resource consumption accounting (RCA) for a hotel. A case study was performed at a 5star hotel in Antalya, Turkey whose room capacity is 350 . Interviews, direct observations, and document collection were used to obtain data while seeking to understand how the RCA method affects analysis results by applying the case study method for a hotel. Results indicated that some customer segments, which are unprofitable by the traditional costing method, are profitable while using RCA. The cost of idle resources devoted to activities in the hotel was also put forth with the case study. Utilizing these results, the hotel management is better able to understand the profitability of different customer segments and implement appropriate strategies. There are limited studies in the literature on profitability analysis in hotel companies and, to the best of author's knowledge, no other research has used the case study method to analyze customer profitability with the RCA method in this field. Therefore, this paper contributes to the literature by analyzing the use of the RCA method for CPA in the real-life case of an actual hotel.
\end{abstract}

\author{
Article History \\ Received 8 June 2021 \\ Revised 26 December 2021 \\ Accepted 29 December 2021 \\ Published online 17 Feb. 2022 \\ Keywords \\ Customer profitability analysis \\ Cost management \\ Resource consumption \\ accounting \\ Hotels
}

\section{INTRODUCTION}

Advances in technology and increasing access to information have fostered the development of new strategic models intended to increase profits. In the 20th century, as the industrial era emerged, companies began to adopt productivity models. The profitability of mass production depended on the ability to achieve cost-effective production and distribution, meaning that

\footnotetext{
1 Address correspondence to Ömer Burak Paksoy (Ph.D.), Gazipasa Mustafa Rahmi Buyukballi Vocational School, Alanya Alaaddin Keykubat University, Antalya, Turkey. E-mail: omer.paksoy@alanya.edu.tr
} 
the focus was on costs and capacities (Schafer, 1999). These developments in manufacturing companies have also been experienced by service companies, and especially hotels.

Accommodation companies, like other businesses, aim to satisfy and retain their customers by increasing and differentiating the products and services they offer. The ability to provide high-quality service to existing and potential customers increases customer satisfaction and loyalty and ensures that the company is preferred by those customers in the future. Companies have accordingly started to develop various programs to retain their profitable customers by analyzing the profitability of their customers in addition to the product profitability (Gündüz, 2002; Koşan, 2008).

The customers and customer groups of companies are not homogeneous. Each customer demands different types of products or services, causes different costs, and contributes differently to the operating profit. For this reason, customer profitability is an important concept for service companies (Acar \& Süklüm, 2016; Gül \& Yaslıdağ, 2020).

In customer profitability analysis (CPA), in addition to the revenues of the company, the costs must be managed effectively and calculated accurately. Many approaches to cost and management accounting have been developed recently. One of these newly emerging cost approaches is resource consumption accounting (RCA), which is a contemporary management accounting method (Cengiz, 2011; Öztürk et al., 2019).

The aim of this paper is to illustrate the implementation of CPA with the RCA method in a hotel. A case study was conducted in a 5-star hotel with 350-room capacity operating in Antalya, Turkey. In this process, the aim was to understand how the RCA method affects analysis results by applying the case study method for a hotel. In this context, first, the relevant literature will be reviewed. Information will then be provided about CPA, the stages of the analysis, the RCA method used in this implementation, and the calculation process. The benefits of this analysis for the company and the necessity of CPA will be explained and the research process and results for a 5-star hotel operating in Antalya will subsequently be provided. Results of this study provides both theoretical and practical contributions. 


\section{LITERATURE REVIEW}

\section{Customer Profitability Analysis}

The contribution of each customer to sales revenue is often not equal to the contribution to operating profitability. When calculating customer profitability, it is frequently seen that customers with smaller sales volume have higher profit shares, while customers with larger sales volume have lower profit shares. For this reason, it is necessary to determine the costs of each customer or customer group and compare those costs with the revenue obtained from them. In this way, the profitability of customers or customer groups is revealed (Yükçü, 2007). CPA is the process of determining revenues and costs based on customers or customer groups and revealing their profitability. With this analysis, it is possible to prevent less profitable customers from using business resources in inefficient ways (Dalc1 et al., 2010; Datar \& Rajan, 2018).

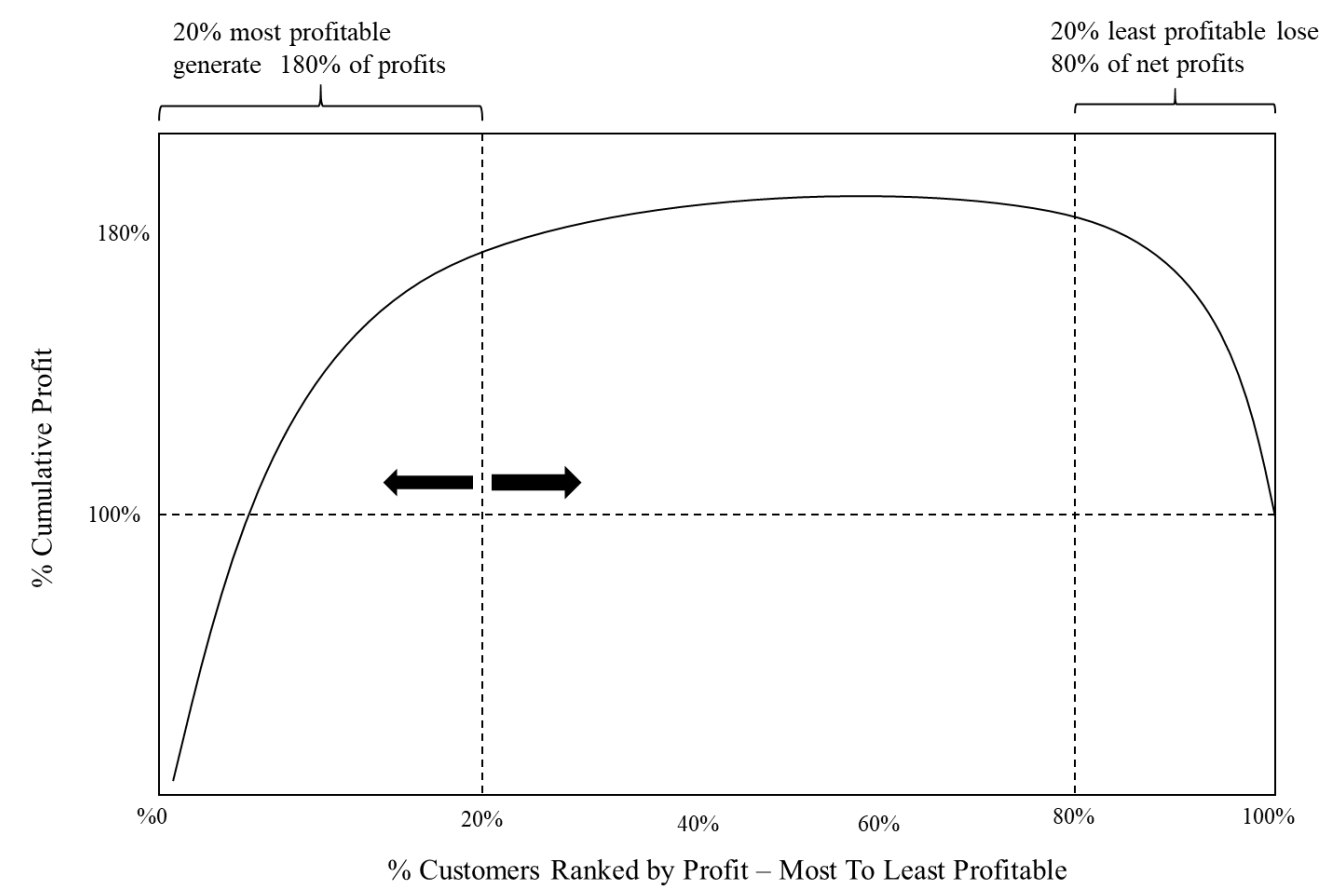

Figure 1. Cumulative Customer Profitability Curve (Whale Curve)

Source: Kaplan and Narayanan (2001, p. 15)

Although the sales volume of customers is considered as an important factor determining profit, different types of service costs incurred for different customers similarly affect operating profit. Customers do not use the same amounts of resources associated with business activities and so selling to some customers may be more costly than selling to others. Therefore, individually calculated customer costs represent different 
customer profits (Özpeynirci \& Kalayc1, 2016). Kaplan and Narayanan (2001) showed the different levels of customer profitability provided by customer groups and their shares in total profit as in Figure 1.

As seen in Figure 1, 20\% of customers generate approximately 180\% of the operating profit. The other $80 \%$ of customers reduce this profit. The customers to the left of the line drawn at 20\% in Figure 1 can be considered as highly profitable customers who should definitely be retained, yielding a profit approximately two times higher than normal. On the other hand, the group to the right of the line drawn at $20 \%$ begins lowering the profit achieved by the previous group, eventually reducing it to $100 \%$. This means that some customers create more value for companies than others (Özpeynirci \& Kalayc1, 2016).

The goal of CPA is to relate the revenues, costs, assets, and resources of companies to their customers. The starting point of this analysis is the calculation of product or service costs. In the next stage, costs are assigned to customers according to marketing and sales processes and then the total cost of each customer is calculated. Finally, these calculated total costs are compared with the revenues obtained from the customers, and customer profitability is thus calculated. CPA, combining revenue and cost data, provides important information to management on a per-customer basis, and this information can help shape long-term decisions. In particular, it provides company managers with material to prepare micro-strategies to increase the profitability of each customer (Yükçü \& Yüksel, 2016).

In this context, CPA assists business management in making many different strategic decisions. It ensures that companies retain existing profitable customers, allows for the re-pricing of highly paid services, and facilitates price reductions to serve low-cost customers. It also enables highprofit customers to be diverted from competitors. It ensures that the customers who constantly create losses are left to competitors, reveals processes related to cost management and profit development, and guarantees that the most appropriate price decisions are made for customers. Finally, it allows management to group customers according to profits and costs within the framework of strategic planning (Ekergil \& Polat, 2020; Pazarçeviren \& Aydın, 2020).

In order to carry out CPA, some specific steps must be followed. These are the creation of customer profiles and the identification of active customers, determination of the revenues generated from each customer or customer group, calculation of the costs of products and services offered to customers, calculation of customer profitability by comparing revenue and 
cost information, and application of the information obtained as a result of CPA for strategic decision-making (Koşan, 2008; Ören \& Tetik, 2012).

At the stage of calculating customer profitability, revenues and costs need to be analyzed very carefully. Particularly when analyzing costs, there is a need to apply costing methods that will calculate costs accurately and give realistic results. This highlights the importance of contemporary costing methods that eliminate the inadequacies of traditional costing methods and enable effective cost control (Öncel \& Büyükmirza, 2019).

According to Kaplan and Narayanan (2001), it is critical that service companies understand the value of the CPA method due to the increasing sizes and organizational complexity of these companies. CPA is more significant for service companies than for manufacturing companies due to the cost of a service being usually determined by the behavior of the customer. According to Zeithaml and Bitner (1996), the cost of finding and acquiring new customers is five times higher for service companies than the cost of retaining existing customers. Nordling and Wheeler (1992) carried out an application of CPA at the Las Vegas Hilton Hotel, but they concluded that they were not able to allocate fixed costs to activities effectively in that study. Noone and Griffin (1999) conducted a case study at a hotel located in the city center of Dublin in order to test the viability of a system developed by them. Activities were identified at the macro and micro levels, and activity-based costing ( $A B C$ ) was used to assign activity costs to customers. The authors put forth that the hotel's management had not any conception of profits and losses linked with certain customer groups. Menu engineering and the ABC method were employed by Raab and Mayer (2007) to analyze a menu at a restaurant in Hong Kong to calculate the profitability of each item on the menu. They found only 3 of 20 main courses profitable. These findings of earlier studies point out the need for developing an understanding of customer profitability analysis for service companies.

\section{Resource Consumption Accounting}

Accurate financial information will enable a company to make the right decisions, calculate costs accurately, and plan for the future. RCA is a method developed to serve these purposes (Öğ̈̈nç \& Tekşen, 2018). Company managers need more accurate cost and production information due to developments in production processes and increasing competition. RCA has an important role in achieving the determined targets in both 
short-term and long-term investment decisions (Tanış \& Demircioğlu, 2017).

RCA is a contemporary management accounting system that combines the importance attributed to resources by the German management accounting system (GPK: Grenzplankostenrechnung) and the activity perspective of ABC accounting (Aksu, 2013; Kayıhan \& Tepeli, 2016). As a result of RCA being a resource-oriented and quantity-based model, it requires detailed cost analysis. When the decision-making phase is taken into account, it supports managers at the resource level, but not at the product level (Köse \& A ̆gdeniz, 2015).

One of the most well-known contemporary costing methods is ABC. However, this method, frequently used in studies conducted to date, has not been able to provide a solution for cost analysis for most companies in the market, because its implementation requires significant time and cost. In the mid-1990s, the search for alternatives to ABC began, and the timedriven ABC (TDABC) and RCA approaches emerged (Tse \& Gong, 2009). Although RCA and $\mathrm{ABC}$ are similar in terms of the distribution of resources, they have differences in terms of methods used. RCA is resourceoriented and focuses on the short term for consideration of more responsibilities, marginal analyses, and expenses, while the $\mathrm{ABC}$ method focuses more on long-term resource consumption. In addition, in the ABC method, idle capacity is ignored in the distribution of costs (Aktaş, 2013).

There are several significant advantages of the RCA method, as described by various authors (Clinton \& Webber, 2004; Öğünç \& Tekşen, 2018; Tutkavul, 2016). First, the RCA method results in accurate cost assignments and associations established based on specific production processes and their outputs. Second, accurate cost assignments in the RCA method provide the ability to undertake resource planning using only the relevant costs. Third, the use of the replacement cost-based depreciation method in RCA removes the problem of unequal cost distributions for similar products requiring support activities. Fourth, cost assignments based on the causality principle in RCA prevent irrelevant costs from being included in product costs. Fifth, the RCA method enables managers to improve their skills in understanding resource relations and using the necessary information in the decisions they will make.

On the other hand, there are also disadvantages of the RCA method as described by Erkuş et al. (2014) and Öktem (2016). First, ERP software programs such as SAP are required. Second, idle capacity costs are an uncertain factor for businesses. Third, RCA is a complex and costly system. 
Fourth, the RCA method is difficult to update because it contains detailed calculations and is difficult to understand.

The application stages of RCA are as follows (Küçük \& Karaca, 2017): In the first stage, the relationships between resources are examined and resource pools are determined. Control and planning are done at the resource level. Thus, resource pools are created by determining the relations of resources with each other. The second stage entails the determination of primary and secondary costs. These costs, if any, are determined for each research pool and total costs are calculated. In the third stage, the costs collected in the resource pools are divided proportionally and fixed. The reason for this fixed and proportional separation of costs is that fixed costs depend on theoretical capacity and proportional costs are allocated according to the output amount of the resource pool. Next, in the fourth stage, activities are determined. Fixed and proportional costs collected in resource pools are distributed to activities through resource cost drivers, and the costs of activities are determined in this way. By comparing the capacity of each resource pool with the theoretical capacity, idle capacity and idle cost are determined. Finally, in the fifth stage, the activity costs determined in the previous stage are distributed to products or services in proportion to the amount of use of the activities, and the product or service cost is thus determined.

The literature review shows that the RCA method was not used earlier in CPA for hotel companies. The lack of studies on the application of the RCA method in the accommodation sector and using the RCA method in CPA represents a significant gap in the literature, and the present study aims to contribute to the literature by filling this gap. In addition, it is expected that the findings of this study will help hotel managers in making decisions regarding pricing, marketing, capacity management, cost management, and other managerial functions.

\section{METHODOLOGY}

\section{Case Study}

The case study method, as one of the methods used in the social sciences, was applied at the hotel selected for this analysis. Case studies are among the most suitable research methods for those working in the fields of cost and management accounting (Koşan, 2008). In this context, a descriptive case study was carried out at the selected hotel, the hotel's existing service 
production and cost system was examined, and efforts were made to understand the relevant profitability calculations.

\section{Data Collection}

The data used in this analysis are real-world data covering a one-year period from January 2019 to December 2019. During the data collection phase, interviews and various observations were held with both employees and senior managers. All financial data given in this study are expressed in Turkish lira (TL). In the calculations, two digits after the decimal point were taken into account.

\section{General Information about the Hotel}

The hotel is located $12 \mathrm{~km}$ from Alanya and $45 \mathrm{~km}$ from Gazipaşa Airport and is open all year. Providing service with an all-inclusive concept, this family-oriented hotel was established on $24,000 \mathrm{~m}^{2}$ with a large green area, consisting of 6 blocks and a total of 350 rooms (with 700-bed capacity). The services offered by the hotel include food, beverages, accommodation, Turkish bath/sauna, spa, bars, swimming pools, sporting activities, convention centers, and entertainment activities.

The research presented here is based on 2019 data, when the average length of stay for customers was 7 days. The hotel had an $80 \%$ occupancy rate in 2019. Children accounted for approximately $10 \%$ of the room occupancy rate, and additional beds were used by $10 \%$ of the customers. More explicit details are as follows:

Room occupancy rate $=350 \times 0.80=280$ rooms

Bed occupancy rate $=700 \times 0.80=560$ people (adults)

Number of children $=280 \times 0.10=28$ children

Number of customers utilizing additional beds $=280 \times 0.10=28$ people (adults)

Total number of customers per week $=616$ people $(560+28+28)$

Total number of customers per month $=616 \times 4=2,464$ people

Total number of customers per year $=2,464 \times 12=29,568$ people

Number of overnight $(\mathrm{O} / \mathrm{N})$ stays per month $=2,464 \times 7=17,248 \mathrm{O} / \mathrm{N}$ stays

Number of overnight $(\mathrm{O} / \mathrm{N})$ stays per year $=17,248 \times 12=206,976 \mathrm{O} / \mathrm{N}$ stays

The number of personnel at the hotel varies during peak periods. However, in practice, it is assumed that an average of 245 personnel are working. The number of personnel on the basis of departments and square meters occupied by hotel areas are shown in Table 1. 
Table 1. Number of personnel and square meters of areas of the hotel

\begin{tabular}{lclc}
\hline Departments & $\begin{array}{c}\text { Number of } \\
\text { Personnel }\end{array}$ & Area & $\begin{array}{c}\text { Square Meters of } \\
\text { Area } \mathbf{( m}^{\mathbf{2}}\end{array}$ \\
\hline Front Office & 16 & Front Office & 80 \\
Housekeeping & 47 & Rooms & 8,000 \\
Service & 38 & Park and Garden & 7,500 \\
Kitchen & 38 & Beach & 5,000 \\
Animation & 15 & Service & 200 \\
Park and Garden & 14 & Kitchen & 400 \\
Laundry & 10 & Restaurant & 660 \\
Doctor & 1 & Laundry & 60 \\
Security & 12 & Bars (Pool/Lobby) & 900 \\
Administrative & 18 & Amphitheater & 300 \\
Technical Service & 21 & Turkish Bath/Sauna & 250 \\
Purchasing & 5 & Convention Centers & 500 \\
Accounting/Finance & 10 & Management Office & 150 \\
\hline TOTAL & $\mathbf{2 4 5}$ & TOTAL & $\mathbf{2 4 , 0 0 0}$ \\
\hline
\end{tabular}

\section{Determination of Customer Groups}

The hotel's customers were categorized within four groups as a result of the conducted interviews:

Group 1: This group comprises customers brought to the hotel by travel agencies and tour operators. It has the highest sales mix percentage $(85 \%)$ among the determined groups. The customers clustered in this group prefer the all-inclusive services of the hotel.

Group 2: These are "walk-in" customers who arrive at the hotel without advance reservations. These customers use the all-inclusive services and have an $8 \%$ share in the total.

Group 3: This group includes customers organizing events or wedding ceremonies in the hotel and has a $5 \%$ share in the total sales mix. Guests in this group receive catering and entertainment services and they stay in the hotel for 1 or 2 days.

Group 4: These customers hold meetings, seminars, and conferences in the hotel. Customers in this group receive catering and might stay in the hotel for 1 or 2 days. This group has a $2 \%$ percent share in the total.

\section{Revenues of the Hotel}

The revenue-generating departments in the hotel are generally those that are in direct contact with customers. In practice, the main revenues of the hotel examined here are reported as arising from accommodations, bars, the restaurant, meetings, and banquet revenues. The hotel's annual revenue distribution is summarized in Table 2 on the basis of customer groups. 
Table 2. Annual revenues of the hotel

\begin{tabular}{lrrrrrr} 
Customer & \multicolumn{9}{c}{ Revenues (TL) } & TOTAL \\
Groups & Accommodations & Bars & Restaurant & Meetings & $\begin{array}{c}\text { Banquets or } \\
\text { Ceremonies }\end{array}$ & \multicolumn{1}{c}{$\begin{array}{c}\text { (TL) } \\
\text { Group 1 }\end{array}$} \\
\cline { 2 - 6 } Group 2 & $6,879,681$ & $1,036,664$ & $1,507,875$ & & & $9,424,220$ \\
Group 3 & $3,914,301$ & 589,826 & 857,929 & & & $5,362,056$ \\
Group 4 & 24,373 & & & & 788,060 & 812,433 \\
TOTAL & 45,496 & & & 584,952 & 19,498 & 649,946 \\
& $\mathbf{1 0 , 8 6 3 , 8 5 1}$ & $\mathbf{1 , 6 2 6 , 4 9 0}$ & $\mathbf{2 , 3 6 5 , 8 0 4}$ & $\mathbf{5 8 4 , 9 5 2}$ & $\mathbf{8 0 7 , 5 5 8}$ & $\mathbf{1 6 , 2 4 8 , 6 5 6}$ \\
\hline
\end{tabular}

The "accommodations" revenues presented in Table 2 generally consist of room sales. Bar and restaurant revenues, excluding the allinclusive system, consist of a la carte restaurant revenues and some beverage revenues not included in the all-inclusive package system. Meeting revenues are generated from organized events such as conferences, seminars, panels, and workshops. Banquet and ceremony revenues are from social groups such as weddings and parties.

\section{Implementation of the Resource Consumption Accounting Method for the Hotel}

In this study, an application was carried out to show how RCA using contemporary costing methods in cost calculations can be applied for the CPA of a hotel. The RCA process performed in this application with the data obtained from the hotel is shown in Figure 2.
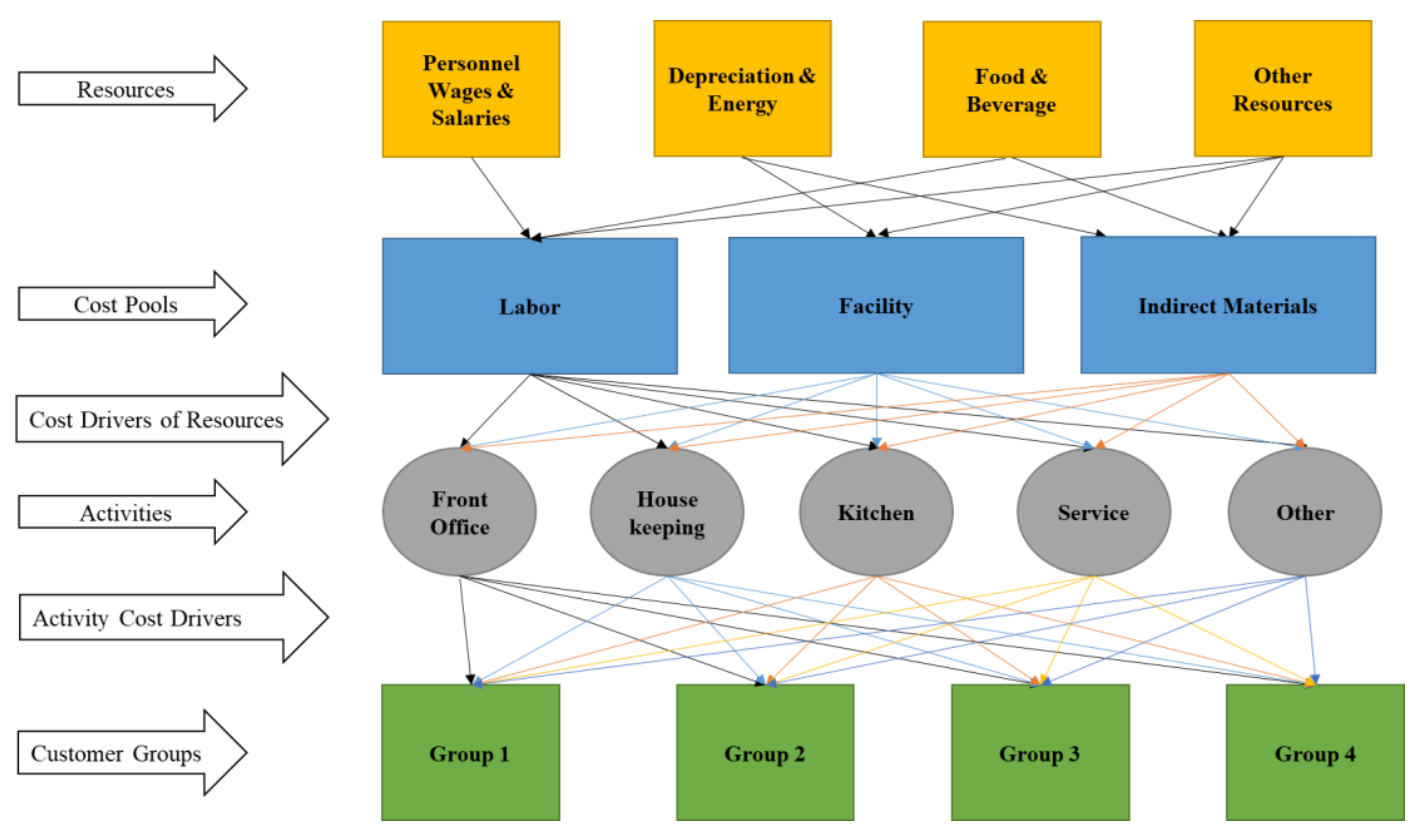

Figure 2. Implementation process of resource consumption accounting for the hotel 
Costs assigned from resources to activities according to resource cost drivers are distributed to cost objects from activities through activity cost drivers (the criterion for using the activities of cost objects). This flow of resource costs to cost objects in RCA is shown in Figure 2.

In the implementation stages of RCA, six steps are undertaken as explained in more detail above. Briefly, these steps are: 1) Identification of resources and costs of resources; 2) Creation of resource pools by considering the relationships between each resource and determination of cost drivers; 3) Classification of costs in resource pools; 4) Identification of activities and allocation of resource costs to activities; 5) Assigning activity costs to cost objects; and 6) Cost control and management.

\section{Identification of Resources and Costs of Resources}

As the first step of RCA, the types of resources and total resource costs of the hotel were determined, as shown in Table 3.

Table 3. Resources and total costs of the hotel

\begin{tabular}{lcc}
\hline Resources & Costs (TL) & Share in the Total (\%) \\
\hline Staff Food and Beverage & $240,858.28$ & $1.85 \%$ \\
Personnel Transport and Lodging Expenses & $166,382.82$ & $1.28 \%$ \\
Electricity & $171,834.30$ & $1.32 \%$ \\
Water & $45,391.89$ & $0.35 \%$ \\
Landscaping and Pool Maintenance & $59,946.58$ & $0.46 \%$ \\
Laundry & $18,154.66$ & $0.14 \%$ \\
Phones & $55,387.83$ & $0.42 \%$ \\
Depreciation & $1,455,363.15$ & $11.16 \%$ \\
Food & $2,463,079.37$ & $18.89 \%$ \\
Beverages & $1,569,465.42$ & $12.04 \%$ \\
Cleaning Equipment & $136,370.03$ & $1.05 \%$ \\
Stationery and Printed Forms & $35,532.78$ & $0.27 \%$ \\
Chemical Materials & $73,206.63$ & $0.56 \%$ \\
Boucle Materials & $23,429.21$ & $0.18 \%$ \\
LPG & $258,339.39$ & $1.98 \%$ \\
Vehicle Fuel & $93,385.48$ & $0.72 \%$ \\
Service Materials & $11,906.45$ & $0.09 \%$ \\
Maintenance & $45,564.08$ & $0.35 \%$ \\
Spare Parts & $33,213.17$ & $0.25 \%$ \\
Electrical Materials & $37,700.00$ & $0.29 \%$ \\
Plumbing Materials & $12,989.99$ & $0.10 \%$ \\
Personnel Wages & $5,991,587.73$ & $45.96 \%$ \\
Insurance & $38,546.73$ & $0.30 \%$ \\
TOTAL & $\mathbf{1 3 , 0 3 7 , 6 3 6 . 0 0}$ & $\mathbf{1 0 0} \%$ \\
\hline
\end{tabular}


The hotel's costs for 2019 are detailed in Table 3. The total resource costs for that year reached 13,037,636 TL, and the largest share of that total belonged to personnel wages at $45.96 \%$. In addition, since an all-inclusive system is applied in this hotel, food and beverage expenses also have an important share in the total cost. The share of food expenditures in the total is $18.89 \%$ and that of beverage expenditures is $12.04 \%$.

\section{Creating Resource Pools and Determination of Cost Drivers}

RCA envisages a homogeneous combination of resources in resource pools within the framework of cause-and-effect relationships, monitoring them according to their structures, behaviors, and capacities. For the hotel in this case study, in light of the relations between resources, a total of three resource pools were created for labor, facility, and indirect materials, respectively. These resource pools were created based on the nature of the resource costs and their relationships with each other, as shown in Table 4.

Table 4. Resource pools

\begin{tabular}{lrr}
\hline Resources & Costs (TL) & Resource Pools \\
\hline Staff Food and Beverage & $240,858.28$ & Labor \\
Personnel Transport and Lodging Expenses & $166,382.82$ & Labor \\
Electricity & $171,834.30$ & Facility \\
Water & $45,391.89$ & Facility \\
Landscaping and Pool Maintenance & $59,946.58$ & Facility \\
Laundry & $18,154.66$ & Facility \\
Phones & $55,387.83$ & Labor \\
Depreciation & $1,455,363.15$ & Facility \\
Food & $2,463,079.37$ & Indirect Materials \\
Beverages & $1,569,465.42$ & Indirect Materials \\
Cleaning Equipment & $136,370.03$ & Indirect Materials \\
Stationery and Printed Forms & $35,532.78$ & Indirect Materials \\
Chemical Materials & $73,206.63$ & Indirect Materials \\
Boucle Materials & $23,429.21$ & Indirect Materials \\
LPG & $258,339.39$ & Facility \\
Vehicle Fuel & $93,385.48$ & Facility \\
Service Materials & $11,906.45$ & Indirect Materials \\
Maintenance & $45,564.08$ & Facility \\
Spare Parts & $33,213.17$ & Facility \\
Electrical Materials & $37,700.00$ & Facility \\
Plumbing Materials & $12,989.99$ & Facility \\
Personnel Wages & $5,991,587.73$ & Labor \\
Insurance & $38,546.73$ & Facility \\
TOTAL & $\mathbf{1 3 , 0 3 7 , 6 3 6 . 0 0}$ & \\
\hline & &
\end{tabular}


In Table 4, expenses such as wages, transportation, lodging, phones, and staff food and beverage costs are assigned to the labor resource pool. Costs such as electricity, water, pool maintenance, landscaping, laundry, depreciation, LPG, vehicle fuels, insurance, and various materials related to the facility in general are grouped in the facility resource pool. Finally, costs such as food, beverages, cleaning equipment, stationery, chemical materials, and boucle materials are categorized within the indirect materials resource pool. Table 5 further summarizes the total costs for each resource pool and the cost drivers to be used in the distribution of resource pools to activity centers.

Table 5. Total costs of resource pools and cost drivers

\begin{tabular}{lrr}
\hline Resource Pools & Total Amount (TL) & Cost Drivers \\
\hline Labor & $6,454,216.67$ & Labor Hours \\
Facility & $2,270,429.42$ & Square Meters of Area \\
Indirect Materials & $4,312,989.90$ & Kilograms \\
TOTAL & $\mathbf{1 3 , 0 3 7 , 6 3 6 . 0 0}$ & \\
\hline
\end{tabular}

In the labor resource pool, "labor hours" was taken as the most appropriate cost driver due to the changes in the number of personnel over a calendar year and the inability to employ them steadily. In the facility resource pool, "square meters of area" was chosen as the cost driver in the distribution of the related expenses. Finally, in the indirect materials resource pool, "kilograms" was chosen as the cost driver.

\section{Classification of Costs in Resource Pools}

After determining the resource pools, the fixed and proportional (variable) parts of the resources within the resource pools should be determined. It is important to distinguish between fixed and proportional costs in the calculation of idle capacity cost, which is one of the features that makes the RCA method superior to other contemporary costing methods. The distribution of fixed and proportional costs incurred in the resource pools of the hotel is summarized in Table 6.

Table 6. Fixed and proportional costs by resource pools

\begin{tabular}{lrrr}
\hline Resource Pools & $\begin{array}{r}\text { Fixed Costs } \\
(\mathbf{T L})\end{array}$ & $\begin{array}{r}\text { Proportional Costs } \\
(\mathbf{T L})\end{array}$ & $\begin{array}{r}\text { TOTAL } \\
(\text { TL) }\end{array}$ \\
\hline Labor & $462,628.94$ & $5,991,587.73$ & $6,454,216.67$ \\
Facility & $1,577,813.03$ & $692,616.39$ & $2,270,429.42$ \\
Indirect Materials & - & $4,312,989.90$ & $4,312,989.90$ \\
\hline
\end{tabular}


In Table 6, while the labor resource pool and facility resource pool include both proportional and fixed costs, the indirect materials resource pool includes only proportional costs. The costs for these resource pools were calculated as fixed and/or proportional according to resource cost drivers as follows:

Labor Resource Pool: Although the daily number varies throughout the year, a total of 245 personnel work in the hotel. The distribution of these personnel by departments was shown in Table 1. While the food and beverage, personnel transportation, lodging, and phone expenses related to the personnel are considered as fixed costs, their wages are defined as proportional costs.

Facility Resource Pool: Depreciation, spare parts, electrical materials, plumbing materials, and insurance expenses are defined as fixed costs. Electricity, water, landscaping, pool maintenance, laundry, LPG, vehicle fuel, and maintenance costs are considered as proportional costs.

Indirect Materials Resource Pool: The costs in the indirect materials resource pool are classified as completely proportional.

As stated above, final costs are calculated based on theoretical and practical capacity in the RCA method. "Theoretical capacity" refers here to the current capacity of the resource pools, while "practical capacity" refers to the output amount. Fixed and proportional cost rates of the resource pools were calculated based on theoretical and practical capacity amounts, respectively. The fixed cost ratio was calculated by dividing the fixed costs by the theoretical capacity and the proportional cost ratio was calculated by dividing the proportional costs by the practical capacity.

Table 7. Theoretical and practical capacities and rates of resource pools

\begin{tabular}{lrrrr}
\hline Resource Pools & $\begin{array}{r}\text { Theoretical } \\
\text { Capacity }\end{array}$ & $\begin{array}{r}\text { Practical } \\
\text { Capacity }\end{array}$ & $\begin{array}{r}\text { Fixed } \\
\text { Cost Ratio }\end{array}$ & $\begin{array}{r}\text { Proportional } \\
\text { Cost Ratio }\end{array}$ \\
\hline Labor & 804,825 & 684,102 & 0.57 & 8.76 \\
Facility & 24,000 & 24,000 & 65.74 & 28.86 \\
Indirect Materials & - & $10,695,500$ & 0.00 & 0.40 \\
\hline
\end{tabular}

In Table 7, the theoretical capacity is provided according to the fixed cost while practical capacity is determined according to proportional costs. Theoretical capacity emerges as a result of working at the maximum level and practical capacity is considered as the capacity desired to be reached within a specified period. The theoretical and practical capacities of the labor resource pool were determined according to annual labor hours, the capacities of the facility resource pool were determined according to the area used (square meters), and the capacity of the indirect material resource pool was determined according to the amount of material in kilograms. The 
fixed and proportional cost ratios described below were calculated to obtain the values seen in Table 7 .

\section{Labor Resource Pool}

Labor Fixed Cost Ratio $=$ Labor Fixed Cost $/$ Labor Theoretical Capacity

In general, when the maximum working time of an employee is 9 hours per day, one year of total working time is accordingly 3,285 hours ( $=9$ $\times$ 365). The theoretical working capacity of 245 personnel was thus calculated as 804,825 labor hours $(=3,285 \times 245)$.

Labor Fixed Cost Ratio $=462,628.94 / 804,825=0.57$ TL/Labor Hour

When the annual leave of the personnel, public holidays, breaks, and idle time are deducted from the theoretical capacity, the practical capacity corresponds to approximately $85 \%$ of the theoretical capacity, which is 684,102 labor hours in the present case.

Labor Proportional Cost Ratio $=$ Labor Proportional Cost $/$ Labor Practical Capacity Labor Proportional Cost Ratio = 5,991,587.73 / 684,102 = 8.76 TL/Labor Hour

\section{Facility Resource Pool}

The areas used in the hotel encompass $24,000 \mathrm{~m}^{2}$ in total and the theoretical and practical capacity is equal.

Facility Fixed Cost Ratio $=$ Facility Fixed Cost $/$ Facility Theoretical Capacity

Facility Fixed Cost Ratio $=1,577,813.03 / 24,000=65.74 \mathrm{TL} / \mathrm{m}^{2}$

Facility Proportional Cost Ratio $=$ Facility Proportional Cost $/$ Facility Practical Capacity

Facility Proportional Cost Ratio $=692,616.39 / 24,000=28.86 \mathrm{TL} / \mathrm{m}^{2}$

\section{Indirect Materials Resource Pool}

Since the materials in the indirect resource pool are directly related to service costs, this pool does not have a theoretical capacity. The practical capacity was determined as 10,695,500 kilograms per year.

Ind. Mat. Proportional Cost Ratio = Ind. Mat. Proportional Cost / Ind. Mat. Practical Capacity

Ind. Mat. Proportional Cost Ratio $=4,312,989.90 / 10,695,500=0.40 \mathrm{TL} / \mathrm{kg}$ 


\section{Identification of Activities and Allocation of Resource Costs to Activities}

As a result of the observations carried out in the hotel and face-to-face interviews with hotel personnel, including managers, it was determined that four main activities (front office, housekeeping, service, and kitchen) and one "other" activity category (general and administrative expenses) were carried out. While determining these activity centers, similar activities were carefully gathered within a single activity pool. Thus, unnecessary activity centers were avoided. The determined activity centers and the amount of resources consumed by these centers are shown in Table 8.

Table 8. Resources consumed by activities

\begin{tabular}{lrrrrrr}
\hline Resource Pools & $\begin{array}{r}\text { Front } \\
\text { Office }\end{array}$ & Housekeeping & Kitchen & Service & Other & TOTAL \\
& 44,676 & 131,236 & 106,106 & 106,106 & 295,978 & 684,102 \\
Labor & 80 & 8,060 & 400 & 1,760 & 13,700 & 24,000 \\
Facility & 700,000 & $2,750,000$ & $3,500,000$ & $2,500,000$ & $1,245,500$ & $10,695,500$ \\
Indirect Materials & & & &
\end{tabular}

The calculations of the values shown in Table 8 are shown below.

\section{Labor Resource Pool}

As detailed in Table 1, the hotel employs 16 workers in the front office activity center, 47 workers in the housekeeping activity center, 38 workers in the service activity center, 38 workers in the kitchen activity center, and 106 workers in the "other" activity center.

Resource Consumption in the Labor Resource Pool of the Front Office Activity Center

$=($ Labor Practical Capacity $/$ Total Number of Personnel in the Hotel $) \times$ Number of Front Office Personnel

$=(684,102 / 245) \times 16=44,676$ Labor Hours

Resource Consumption in the Labor Resource Pool of the Housekeeping Activity Center

$=($ Labor Practical Capacity $/$ Total Number of Personnel $) \times$ Number of Housekeeping Personnel

$=(684,102 / 245) \times 47=131,236$ Labor Hours

Resource Consumption in the Labor Resource Pool of the Kitchen Activity Center

$=($ Labor Practical Capacity $/$ Total Number of Personnel $) \times$ Number of Kitchen Personnel

$=(684,102 / 245) \times 38=106,106$ Labor Hours

Resource Consumption in the Labor Resource Pool of the Service Activity Center 
$=($ Labor Practical Capacity $/$ Total Number of Personnel $) \times$ Number of Service Personnel

$=(684,102 / 245) \times 38=106,106$ Labor Hours

Resource Consumption in the Labor Resource Pool of the "Other" Activity Center

$=($ Labor Practical Capacity $/$ Total Number of Personnel $) \times$ Number of "Other" Activity Personnel

$=(684,102 / 245) \times 106=295,978$ Labor Hours

Data on the area $\left(\mathrm{m}^{2}\right)$ used by the activities in the facility resource pool and the amount of material $(\mathrm{kg})$ are as follows according to information received from management: Inside the hotel, the front office activities take place in an area of $80 \mathrm{~m}^{2}$, housekeeping activities in an area of $8,060 \mathrm{~m}^{2}$, kitchen activities in an area of $400 \mathrm{~m}^{2}$, service activities in an area of $1,760 \mathrm{~m}^{2}$, and other activities in an area of $13,700 \mathrm{~m}^{2}$ in total. Furthermore, $700,000 \mathrm{~kg}$ of resources are consumed in front office activities, 2,750,000 $\mathrm{kg}$ in housekeeping activities, 3,500,000 kg in kitchen activities, $2,500,000 \mathrm{~kg}$ in service activities, and 1,245,500 kg in other activities as indirect materials in the course of a year.

In the next stage of analysis, the costs in the resource pools are distributed to activities as seen in Table 9.

Table 9. Distribution of costs collected in resource pools to activities

\begin{tabular}{lrrrrrr}
\hline Resource Pools & $\begin{array}{r}\text { Front } \\
\text { Office (TL) }\end{array}$ & $\begin{array}{r}\text { Housekeeping } \\
\text { (TL) }\end{array}$ & $\begin{array}{r}\text { Kitchen } \\
\text { (TL) }\end{array}$ & $\begin{array}{r}\text { Service } \\
\text { (TL) }\end{array}$ & $\begin{array}{r}\text { Other } \\
\text { (TL) }\end{array}$ & $\begin{array}{r}\text { TOTAL } \\
\text { (TL) }\end{array}$ \\
\hline Labor & 416,968 & $1,224,844$ & 990,303 & 990,303 & $2,762,405$ & $6,384,822$ \\
Facility & 7,568 & 762,486 & 37,840 & 166,498 & $1,296,037$ & $2,270,429$ \\
Indirect Materials & 282,277 & $1,108,945$ & $1,411,385$ & $1,008,132$ & 502,251 & $4,312,990$ \\
TOTAL & $\mathbf{7 0 6 , 8 1 3}$ & $\mathbf{3 , 0 9 6 , 2 7 5}$ & $\mathbf{2 , 4 3 9 , 5 2 8}$ & $\mathbf{2 , 1 6 4 , 9 3 3}$ & $\mathbf{4 , 5 6 0 , 6 9 4}$ & $\mathbf{1 2 , 9 6 8 , 2 4 1}$ \\
\hline
\end{tabular}

Table 9 provides data related to the distribution of the costs collected in the resource pools to activities. The calculations of these values were performed as follows:

\section{Labor Resource Pool}

Front Office Activity Center $=44,676 \times(0.57+8.76)=416,968 \mathrm{TL}$

Housekeeping Activity Center $=131,236 \times(0.57+8.76)=1,224,844 \mathrm{TL}$

Kitchen Activity Center $=106,106 \times(0.57+8.76)=990,303 \mathrm{TL}$

Service Activity Center $=106,106 \times(0.57+8.76)=990,303 \mathrm{TL}$

“Other" Activity Center $=295,978 \times(0.57+8.76)=2,762,405 \mathrm{TL}$ 


\section{Facility Resource Pool}

Front Office Activity Center $=80 \times(65.74+28.86)=7,568 \mathrm{TL}$

Housekeeping Activity Center = 8,060 × $(65.74+28.86)=762,486 \mathrm{TL}$

Kitchen Activity Center $=400 \times(65.74+28.86)=37,840 \mathrm{TL}$

Service Activity Center $=1,760 \times(65.74+28.86)=166,498 \mathrm{TL}$

"Other" Activity Center $=13,700 \times(65.74+28.86)=1,296,037 \mathrm{TL}$

\section{Indirect Materials Resource Pool}

Front Office Activity Center $=700,000 \times(0+0.40)=282,277 \mathrm{TL}$

Housekeeping Activity Center $=2,750,000 \times(0+0.40)=1,108,945 \mathrm{TL}$

Kitchen Activity Center $=3,500,000 \times(0+0.40)=1,411,385 \mathrm{TL}$

Service Activity Center $=2,500,000 \times(0+0.40)=1,008,132 \mathrm{TL}$

“Other" Activity Center = 1,245,500 × $(0+0.40)=502,251 \mathrm{TL}$

\section{Assigning Activity Costs to Cost Objects}

In the fifth step of the RCA method, the activity cost drivers and the amount of resources consumed by the activities within the cost objects are determined. The costs accumulated in the activity centers are then distributed to the cost objects by allocation rates. Table 10 shows the activity centers and activity drivers to be used in the distribution of the costs collected in these centers to the customer groups.

Table 10. Determining activity cost drivers and consumed resources by cost objects

\begin{tabular}{lcrrrrr}
\hline Activities & Activity Cost Drivers & Group 1 & Group 2 & Group 3 & Group 4 & TOTAL \\
\hline Front Office & Number of Customers & 25,133 & 2,365 & 1,478 & 591 & 29,568 \\
Housekeeping & Number of Activities & $3,302,338$ & $2,101,488$ & 420,298 & 180,128 & $6,004,250$ \\
Kitchen & Number of O/N Stays & 113,837 & 72,442 & 14,488 & 6,209 & 206,976 \\
Service & Number of O/N Stays & 113,837 & 72,442 & 14,488 & 6,209 & 206,976 \\
Other & Number of O/N Stays & 113,837 & 72,442 & 14,488 & 6,209 & 206,976 \\
\hline
\end{tabular}

In Table 10, the activity cost drivers to be used in the distribution of the costs in the activity pools to the cost objects and the customer groups defined as the cost objects are indicated. The resources consumed by these activities were determined. Accordingly, the distribution of costs collected in the front office activity center will be based on "number of customers," the distribution of costs collected in the housekeeping activity center will be based on "number of activities," and the distribution of costs collected in 
the remaining activity centers (kitchen, service, and "other") will be based on "number of $\mathrm{O} / \mathrm{N}$ stays" as activity cost drivers.

Table 11 provides data on the distribution of costs collected in activity centers to customer groups.

Table 11. Distribution of costs collected in activities to customer groups

\begin{tabular}{lrrrrr}
\hline Activities & $\begin{array}{r}\text { Group 1 } \\
\text { (TL) }\end{array}$ & $\begin{array}{r}\text { Group 2 } \\
\text { (TL) }\end{array}$ & $\begin{array}{r}\text { Group 3 } \\
\text { (TL) }\end{array}$ & $\begin{array}{r}\text { Group 4 } \\
\text { (TL) }\end{array}$ & $\begin{array}{r}\text { TOTAL } \\
\text { (TL) }\end{array}$ \\
\hline Front Office & 600,791 & 56,545 & 35,341 & 14,136 & 706,813 \\
Housekeeping & $1,702,951$ & $1,083,696$ & 216,739 & 92,888 & $3,096,275$ \\
Kitchen & $1,341,740$ & 853,835 & 170,767 & 73,186 & $2,439,528$ \\
Service & $1,190,713$ & 757,726 & 151,545 & 64,948 & $2,164,933$ \\
Other & $2,508,381$ & $1,596,243$ & 319,249 & 136,821 & $4,560,694$ \\
TOTAL & $\mathbf{7 , 3 4 4 , 5 7 6}$ & $\mathbf{4 , 3 4 8 , 0 4 5}$ & $\mathbf{8 9 3 , 6 4 1}$ & $\mathbf{3 8 1 , 9 7 9}$ & $\mathbf{1 2 , 9 6 8 , 2 4 1}$ \\
\hline
\end{tabular}

The calculations made for each activity center were performed as follows:

\section{Front Office Activity Center}

In the distribution of the costs collected in the front office activity center to customer groups, "number of customers" is determined as the activity cost driver. The allocation rate for this activity center is as follows:

Allocation Rate $=706,813 / 29,568=23.91 \mathrm{TL} /$ person

By using the calculated allocation rate, the costs in the front office activity center are allocated to customer groups as follows:

Customer Group $1=23.91 \times 25,133=600,791 \mathrm{TL}$

Customer Group $2=23.91 \times 2,365=56,545 \mathrm{TL}$

Customer Group $3=23.91 \times 1,478=35,341 \mathrm{TL}$

Customer Group $4=23.91 \times 591=14,136 \mathrm{TL}$

\section{Housekeeping Activity Center}

In the distribution of the costs collected in the housekeeping activity center to customer groups, "number of activities" is determined as the activity cost driver. The allocation rate for this activity center is calculated as follows:

Allocation Rate $=3,096,275 / 6,004,250=0.52$ TL/activity

By using the calculated allocation rate, the costs in the housekeeping activity center are allocated to customer groups as follows:

Customer Group $1=0.52 \times 3,302,338=1,702,951 \mathrm{TL}$ 
Customer Group $2=0.52 \times 2,101,488=1,083,696 \mathrm{TL}$

Customer Group $3=0.52 \times 420,298=216,739 \mathrm{TL}$

Customer Group $4=0.52 \times 180,128=92,888 \mathrm{TL}$

\section{Kitchen Activity Center}

In the distribution of the costs collected in the kitchen activity center to customer groups, "number of $\mathrm{O} / \mathrm{N}$ stays" is determined as the activity cost driver. The allocation rate for the activity center is calculated as follows:

Allocation Rate $=2,439,528 / 206,976=11.79$ TL/ON Stay

By using the calculated allocation rate, the costs in the housekeeping activity center are allocated to customer groups as follows:

Customer Group $1=11.79 \times 113,837=1,341,740 \mathrm{TL}$

Customer Group $2=11.79 \times 72,442=853,835 \mathrm{TL}$

Customer Group $3=11.79 \times 14,488=170,767 \mathrm{TL}$

Customer Group $4=11.79 \times 6,209=73,186 \mathrm{TL}$

Calculations for the remaining activity centers were carried out similarly. In Table 12, the distributed cost amounts and idle capacity amounts are summarized.

Table 12. Cost allocation summary

\begin{tabular}{lrrr}
\hline Resource Pools & $\begin{array}{r}\text { Costs Incurred } \\
\mathbf{( T L )}\end{array}$ & $\begin{array}{r}\text { Distributed Costs } \\
\text { (TL) }\end{array}$ & $\begin{array}{r}\text { Idle Resource Cost } \\
\text { (TL) }\end{array}$ \\
\hline Labor & $6,454,217$ & $6,384,822$ & 69,395 \\
Facility & $2,270,429$ & $2,270,429$ & 0 \\
Indirect Materials & $4,312,990$ & $4,312,990$ & 0 \\
TOTAL & $\mathbf{1 3 , 0 3 7 , 6 3 6}$ & $\mathbf{1 2 , 9 6 8 , 2 4 1}$ & $\mathbf{6 9 , 3 9 5}$ \\
\hline
\end{tabular}

Idle capacity is calculated as follows based on the data provided in Table 12:

Idle Resource Cost $=$ Costs Incurred - Distributed Costs

Thus, as a result of the RCA application, the total idle capacity of the hotel selected for this case study was calculated as 69,395 TL. Therefore, 69,395 TL was not included in the cost objects. 


\section{RESEARCH FINDINGS}

Costs are allocated to customer groups with the RCA method and the profitability of the customer groups emerges as a result of subtracting the costs of those groups from the revenues obtained from the customer groups. As a result of the application of the RCA method in the present study, customer profitability was determined by the comparison of costs and revenues calculated by the distribution of costs to the customer groups as shown in Table 13.

Table 13. Profitability of customer groups

\begin{tabular}{lrrrc}
\hline Customer Groups & $\begin{array}{r}\text { Revenue } \\
\text { (TL) }\end{array}$ & $\begin{array}{r}\text { Costs } \\
\text { (TL) }\end{array}$ & $\begin{array}{r}\text { Profit / Loss } \\
\text { (TL) }\end{array}$ & $\begin{array}{r}\text { Relative } \\
\text { Profitability }\end{array}$ \\
\hline Group 1 & $9,424,220$ & $7,344,576$ & $2,079,644$ & $63.40 \%$ \\
Group 2 & $5,362,056$ & $4,348,045$ & $1,014,011$ & $30.91 \%$ \\
Group 3 & 812,433 & 893,641 & $-81,208$ & $-2.48 \%$ \\
Group 4 & 649,946 & 381,979 & 267,967 & $8.17 \%$ \\
TOTAL & $\mathbf{1 6 , 2 4 8 , 6 5 6}$ & $\mathbf{1 2 , 9 6 8 , 2 4 1}$ & $\mathbf{3 , 2 8 0 , 4 1 5}$ & $\mathbf{1 0 0 . 0 0 \%}$ \\
\hline
\end{tabular}

In Table 13, the previously calculated idle capacity cost of $69,395 \mathrm{TL}$ was not included in the calculations. This difference is caused by the unused capacity that emerges from activities. In other words, it results from the distribution of costs to customer groups after the costs of the unused capacity are subtracted. This cost difference is crucial information that should be used by managers in decision-making processes.

When the results of the CPA conducted with the RCA method are examined, it is seen that only one of the customer groups (Group 3) causes a loss for the hotel. This may be due to the selection of activity cost drivers used in the allocation of costs belonging to this group. Group 1, on the other hand, is the most profitable customer group with a $63.40 \%$ share in profitability analysis. This customer group is followed by Group 2 with a share of $30.91 \%$. Group 4, comprising customers who come for meetings, has the lowest profitability level among the customer groups.

The costs allocated according to the traditional costing method used by the hotel and those obtained via the RCA method differ although the revenues of the customer groups are the same. This difference is due to the fact that idle capacity is not distributed to the customer groups in contrary with the traditional costing method, and that reveals the change in profitability ratios.

As shown in detail in the previous sections, the costs of the hotel, customer group costs, and customer group revenues were calculated. After 
determining the revenues and costs, the profit and profitability ratios of the customer groups were calculated. Considering the current value and future economic benefits for the company, the hotel management may direct the focus of service toward high-value customers because such customers contribute the highest profits for the hotel. CPA explains customer profitability in a certain past accounting period and thus contributes to the evaluation of the effectiveness of hotel investments. By combining CPA and RCA, management may obtain more comprehensive data regarding its customers and might subsequently be able to make better decisions about customer relationship management and improve the value of the company.

\section{CONCLUSION}

CPA is a technique that has entered the management accounting literature in recent years. In brief, it determines the revenues of customers or customer groups, the costs necessary to obtain those revenues, and the profits as a result. With CPA, the contributions of customer groups to the company are determined instead of the profits obtained from products or services. Therefore, managers can make customer-oriented decisions and increase the necessary attention paid to profitable customers.

In terms of hotel businesses, the contribution of each customer can be calculated using the CPA method. However, this is a very difficult and time demanding analytical process. Analyzing customer groups is more applicable for hotel managers than analyzing individuals. Since customers come to hotels for different reasons, it is easier and more effective in terms of strategic decisions to perform collective analysis by grouping the customers instead of performing customer-based analysis one by one.

The RCA method has emerged as a dynamic, comprehensive, and integrated management accounting approach that combines the process perspective of the ABC method and the resource perspective of GPK. The RCA method is accepted by many academics and practitioners as a costing method that not only eliminates the inadequacies of many methods developed before but it also provides the most advanced and accurate information. With the RCA method, business managers are supported in both short-term and long-term decision-making processes, and it helps to identify inefficient resources and activities by calculating idle capacity costs.

The RCA method considers consumption relations between resources and cost objects on the basis of cause and effect. Many factors are 
taken into account in determining idle capacity and idle capacity costs. The RCA method is defined as a superior method as it eliminates the deficiencies of other costing methods that lead to distorted and erroneous cost information. The traditional costing method only calculates the average cost, the $A B C$ method ignores idle capacity, and the TDABC method takes time as the only factor when calculating the idle costs. If the RCA method is used, significant differences in costs for manufacturing or service companies can be expected. This, in turn, will have a significant positive impact on the pricing policies of the companies.

In the present study, a CPA application was performed for a hotel that did not previously apply CPA and had assumed that all customers provide the same profits. The purpose of this application was to examine the usability of the RCA method in CPA and determine whether it can provide accurate results. In this regard, using the RCA method provides managers to access more precise CPA information and reveals the idle capacity as well.

Five activities in the hotel were emphasized in this case study and the contributions to the hotel of the customer groups belonging to those activity groups were calculated. Clear evidence was obtained to show that these five activity centers have idle capacity. Labor-intensive aspect of hospitality sector is well known and it is also known that staff have a significant influence on the profitability of a hotel. Concordantly, hotel managers should focus on determining proper strategies to maximize capacity utilization. For example, managers might provide the necessary training and motivation to personnel to follow up on and respond to customers' needs and expectations to attract more customers and remove idle capacity in the future. With the RCA approach, hotel managers will be better equipped to comprehend if the capacity is sufficient to meet future needs. This will enable them to plan workforce better, which in turn will encourage the efficient use of human resources. With better workforce planning, management will be able to hire the right type of employees who are aligned with the hotel's needs and they will also be able to anticipate personnel training demands more efficaciously.

In this research, the profitability of different customer groups was calculated and it was found that, with a share of $63.40 \%$, "Customer Group 1 " comprising customers who visited the hotel through travel agencies and tour operators, was the most profitable and made the highest contribution. On the other hand, it was observed that "Customer Group 3" caused a loss in hotel revenues. This finding should be reviewed by the hotel managers 
and necessary decisions should be made. In this context, hotel management should adapt appropriate programs to manage customer relations. For example, hotel managers could carry out different promotional programs or campaigns to attract more profitable customers in several periods. The hotel can divert low-profit customer groups to low seasons and focus on serving high-income groups during peak times. On the other hand, the hotel must also consider measures to retain "Customer Group 1", the most profitable group, in order to maintain profits in future periods. For this reason, the hotel management should establish the marketing strategies required to enhance guest loyalty among this group. This will then allow the hotel to subsidize low-profit contributors with profits from high-profit contributors. In addition, the hotel management will be able to better designate the customer mix that will provide the highest return in the future after obtaining results via RCA analysis.

In addition to the practical results, this study contributes to the literature in some aspects. Earlier, Dalc1 et al. (2010) aimed to show the implementation of CPA using TDABC in a four-star hotel. They conducted a case study that also revealed the cost of idle resources devoted to front office, housekeeping, food preparation, and marketing activities. The results showed that some customer groups were determined profitable using TDABC method in CPA contrary with the traditional costing method. However, the estimation of the time equations that used in TDABC method can be subjective during the application of the method to the hotel business. Therefore, in this study, it was predicted that choosing the RCA model would yield more accurate results. In addition, it is determined that the RCA model, which has been applied in many different sectors, differs according to the results produced by the $\mathrm{ABC}$ and TDABC methods. In fact, in most studies, it has been determined that accurate and reliable information is provided with the newly emerged RCA model comparing to other methods (Clinton \& Webber, 2004; Küçük \& Karaca, 2017; Öğünç \& Tekşen, 2018; Öncel \& Büyükmirza, 2019).

In conclusion, this study aimed to provide guidance for hotel managers in terms of the analysis of the contributions of customer groups and to demonstrate the applicability of the RCA method in CPA for accommodation companies as well as manufacturing companies. This analysis will also help hotel managers make accurate decisions about the investments to be made in their hotels. CPA studies have been previously conducted with both $\mathrm{ABC}$ and TDABC methods, which are widely used in the literature. However, with the use of RCA, which is one of the most advanced costing and cost management techniques, the present work has 
contributed to the literature in terms of both showing the usability of new methods with CPA and increasing the recognition of RCA. The findings obtained here were collected from a case study conducted at a 5-star hotel in Turkey. While the results of this research cannot be generalized to the accommodation sector entirely at this point, they may shed light on hotel cost practices from the perspective of the RCA model. In future research, this work should be replicated at other hotels both in Turkey and abroad, as well as hotels of different stars to determine whether the present results are generalizable.

\section{REFERENCES}

Acar, D., \& Süklüm, N. (2016). Konaklama işletmelerinde herşey dahil sisteminin müşteri karlılık analizi açısından değerlendirilmesi. Muhasebe ve Finansman Dergisi, 71, 122.

Aksu, İ. (2013). Kaynak tüketimine dayalı muhasebe: bir örnek uygulama. E- Journal of New World Sciences Academy, 8(4), 165-182.

Aktaş, R. (2013). Yeni bir maliyet ve yönetim muhasebesi yöntemi olarak kaynak tüketim muhasebesi. Muhasebe ve Finansman Dergisi, 58, 55-76.

Cengiz, E. (2011). Yönetim muhasebesi çerçevesinde yalın muhasebe. Ankara: Gazi Kitabevi.

Clinton, B. D., \& Webber, S. A. (2004). RCA at clopay. Strategic Finance, 86(4), 21-26.

Dalcı, İ., Tanış, V., \& Koşan, L. (2010). Customer profitability analysis with time-driven activity-based costing: a case study in a hotel. International Journal of Contemporary Hospitality Management, 22(5), 609-637.

Datar, S. M., \& Rajan, M.V. (2018). Horngren's cost accounting. 16th Edition, NY: Pearson New York.

Ekergil, V., \& Polat, E. (2020). Muhasebe meslek mensuplarının müşteri karlılık analizi ve bir model önerisi. Muhasebe ve Vergi Uygulamaları Dergisi, 13(2), 257-280.

Erkuş, H., Aksu, İ., \& Turan, E. (2014). Kaynak tüketim muhasebesinin diğer maliyet sistemleri ile karşılaştırılması. Muhasebe ve Vergi Uygulamaları Dergisi, 7(2), 15-36.

Gül, U., \& Yaslıdağ, B. H. (2020). Müşteri karlılık analizlerinde faaliyet tabanlı ile zaman etkenli maliyet yöntemlerinin karşılaştırılması. İstanbul Aydın Üniversitesi Dergisi, 12(2), 153-173.

Gündüz, H. E. (2002). Müşteri karlılık analizi. Muhasebe Bilim Dünyası Dergisi, 4(3), 65-77.

Kaplan, R. S., \& Narayanan, V. G. (2001). Measuring and managing customer profitability. Journal of Cost Management, 15(5), 5-15.

Kayıhan, B., \& Tepeli, Y. (2016). Yeni bir maliyetleme tekniği olarak kaynak tüketim muhasebesi ve bir örnek uygulama. Uluslararası Yönetim İktisat ve Isşletme Dergisi ICAFR 16, (Özel Sayı), 431-443.

Koşan, L. (2008). Faaliyet tabanlı müşteri karlılık analizi: bir konaklama işletmesinde uygulama. Çukurova Üniversitesi Sosyal Bilimler Enstitüsü Dergisi, 17(1), 285-302.

Köse, T., \& Ağdeniz, Ş. (2015). Kaynak tüketim muhasebesinde kapasite maliyet yönetimi. Muhasebe ve Denetime Bakış Dergisi, 45, 51-74.

Küçük, H., \& Karaca, N. (2017). Kaynak tüketim muhasebesi temelinde ürün maliyetlerinin hesaplanması- karşılaştırılmalı bir uygulama. İşletme Araştırmaları Dergisi, 9(2), 353-375. 
Noone, B., \& Griffin, P. (1999). Managing the long term profit yield from market segments in a hotel environment: a case study on the implementation of customer profitability analysis. International Journal of Hospitality Management, 18(2), 111-128.

Nordling, C. W., \& Wheeler, S. K. (1992). Building a market-segment accounting model to improve profits. The Cornell Hotel \& Restaurant Administration Quarterly, 33(3), 2936.

Öğünç, H., \& Tekşen, Ö. (2018). Kaynak tüketim muhasebesi yaklaşımının tuğla üretim işletmesinde uygulanması ve karşılaştırmalı analizi. Muhasebe Bilim Dünyası Dergisi, 20(2), 389-417.

Öktem, B. (2016). Üretim işletmelerinde kaynak tüketim muhasebesine duyulan gereksinim ve uygulama boyutu. Marmara Üniversitesi İktisadi ve İdari Bilimler Dergisi, 38(1), 261-277.

Öncel, M., \& Büyükmirza, K. (2019). Kaynak tüketim muhasebesinin müşteri karlılık analizinde kullanılması: bir üretim işletmesinde uygulama. Ünye İktisadi ve İdari Bilimler Fakültesi Dergisi, 2(2), 18-41.

Ören, V. E., \& Tetik, N. (2012). Zaman etkenli faaliyet tabanlı maliyet yöntemi ile müşteri karlılık analizi: seyahat acentası örnek olayı. Muhasebe Bilim Dünyası Dergisi, 2, 2948.

Özpeynirci, R., \& Kalaycı, E. (2016). Bankalarda müşteri karlılık analizi: bir alan araştırması. Aksaray Üniversitesi Iktisadi ve İdari Bilimler Fakültesi Dergisi, 8(1), 21-36.

Öztürk, M. S., Çarıkçı, O., Yaman, B., \& Ağaç, S. (2019). Bir konaklama işletmesinde kaynak tüketim muhasebesi uygulaması. Mali Çözüm Dergisi, 29(153), 89-107.

Pazarçeviren, S. Y., \& Aydın, E. (2020). Müşteri karlılık analizinde faaliyet tabanlı maliyetleme sisteminin kullanılması ve bir üretim işletmesinde uygulama. Akademik Sosyal Araştırmalar Dergisi, 8(111), 463-482.

Raab, C., \& Mayer, K. (2007). Menu engineering and activity-based costing: can they work together in a restaurant?. International Journal of Contemporary Hospitality Management, 19(1), 43-52.

Schafer, E. (1999). Customer profitability analysis - today. Diploma Thesis, Diplomarbeiten Agentur diplom.de. ein Imprint der Diplomica.

Tanış, İ. F., \& Demircioğlu, E. N. (2017). Kaynak tüketim muhasebesi ve önemi. Çukurova Üniversitesi İ̈BF Dergisi, 21(2), 175-187.

Tse, M. S. C., \& Gong, M. Z. (2009). Recognition of idle resources in time-driven activitybased costing and resource consumption accounting models. Journal of Applied Management Accounting Research, 7(2), 41-54.

Tutkavul, K. (2016). İşletmelerin sürdürülebilir rekabet gücü ve rekabet üstünlü̆g̈ü sağlamada verecekleri stratejik kararların kaynak tüketim muhasebesi modeliyle doğrulanmasına yönelik amprik bir çalışma. Unpublished doctoral dissertation, Dumlupınar University, Kütahya, Turkey.

Yükçü, S. (2007). Yönetim açısından maliyet muhasebesi. İzmir: Birleşik Matbaacılık.

Yükçü, S., \& Yüksel, İ. (2016). Hastane işletmelerinde müşteri karlılığının faaliyete dayalı maliyet yöntemi ile analiz edilmesi ve örnek bir uygulama. Muhasebe ve Denetime Bakış Dergisi, 16(49), 1-18.

Zeithaml, V. A., \& Bitner, M. J. (1996). Service marketing. New York, NY: McGraw-Hill. 